Témoigner Témoigner. Entre histoire et mémoire

Getuigen Revue pluridisciplinaire de la Fondation Auschwitz

$121 \mid 2015$

Violences radicales en scène

\title{
Stef Craps. Postcolonial Witnessing: Trauma out of Bounds
}

Palgrave Macmillan, 2012

\section{Simona Bertacco}

\section{(2) OpenEdition}

\section{Journals}

Electronic version

URL: https://journals.openedition.org/temoigner/3701

DOI: $10.4000 /$ temoigner.3701

ISSN: 2506-6390

Publisher:

Éditions du Centre d'études et de documentation Mémoire d'Auschwitz, Éditions Kimé

Printed version

Date of publication: 1 October 2015

Number of pages: 208-210

ISSN: 2037-4183

\section{Electronic reference}

Simona Bertacco, "Stef Craps. Postcolonial Witnessing: Trauma out of Bounds", Témoigner. Entre histoire et mémoire [Online], 121 | 2015, Online since 01 October 2016, connection on 04 February 2022. URL: http://journals.openedition.org/temoigner/3701 ; DOI: https://doi.org/10.4000/temoigner.3701

This text was automatically generated on 4 February 2022

Tous droits réservés 


\title{
Stef Craps. Postcolonial Witnessing: Trauma out of Bounds
}

Palgrave Macmillan, 2012

\author{
Simona Bertacco
}

\section{REFERENCES}

Stef Craps, Postcolonial Witnessing: Trauma out of Bounds. Palgrave Macmillan, 2012, 284 p.

1 Stef Craps' Postcolonial Witnessing: Trauma Out of Boundsis a brilliant and important book, a book that one hopes will initiate a new phase in postcolonial and trauma studies. In a highly theoretical area such as postcolonialism, the clarity and concreteness of Craps' approach is extremely refreshing. What is inspiring about this study is how it addresses the importance of the textual rendering of the traumatic experience as well as the relevance of testimony and of the ethical responsibility of the audience, and pushes for a careful analysis of the "signifying" work of the literary text that is virtually unseen in postcolonial studies done today.

2 Trauma theory offers a pertinent framework and a terminology to deal with texts that put the legacy of the violence of the European colonial enterprise at their centre. A generalized sense of violence, individual and collective, is often found in postcolonial literary texts that tackle with the complexities of the political situations or of the civil wars that have ravaged many postcolonial nations in recent years. For this reason, it is all the more important, as Craps seems to argue, to make sure that the vocabulary used in trauma theory in the twenty-first century conveys an understanding of trauma that is informed by the specific experience of postcolonial traumas in their variety and, sadly, in their ordinariness. Rethinking trauma theory from a postcolonial vantage pointis an important move to lead the field of trauma studies to embrace a comparative and truly global perspective, and to live up to the promise of "cross-cultural ethical engagement" (2) that has always distinguished this critical practice. The mode of reading the literary texts that trauma theory has insisted upon, in fact, comes invested 
with an ethical significance: listening to the trauma of others can help us move out of the isolation that the experience of trauma builds around the subject, helping to instead imagine new forms of community and of solidarity across groups and cultures. As a reader of postcolonial literary texts, I can relate very intensely to this notion of solidarity established through the act of reading between people divided by contexts, experiences, political regimes, and languages. The emphasis falls on the meaning making process enacted in the act of reading: our interpretation of the work of literature is an interpretation committed to bringing the text and its otherness into our world, to bearing meaning onto our own lives, and to following the text in the creation of new patterns of understanding of the human experience. It is in this sense that our response to the literary text as literature can be understood in ethical terms.

3 Postcolonial Witnessing follows the trajectory of trauma studies since the 1990s and dedicates ample attention to the founders of the field (Caruth, LaCapra, Felman and Daub, Hartman) in the opening chapters, while it interestingly puts the emphasis on creative works dealing with global traumas in the final chapters (specifically, Craps analyses works by Sindiwe Magona, David Dabydeen, Fred D'Aguilar, Caryl Phillips and Anita Desai), providing the author with the ideal material on which to ground his comparative theory.

4 I see three major contributions offered by this volume to the fields of postcolonial and trauma studies.

5 (1) Craps establishes the new category of "colonial traumas" within the Eurocentric paradigm of trauma discourse, and uses it to approach the textual rendering of traumatic experiences across a broad range of literary texts. Taken together, the chapters in this volume point to a new area of development for postcolonial trauma studies which theorizes trauma, violence, history, and truth in postcolonial (con)texts by looking at several compatible, not identical contexts, simultaneously. What can be learned through this comparative perspective is that not all experiences of trauma are alike, that the event-based and individual-based parameters through which trauma experiences have been studied in Western culture do not help us understand groupbased, "insidious", i.e. pervasive, systemic and almost unnoticeable, experiences of trauma. In chapter 2 of his book, for example, Craps replaces Freud with Fanon as a forefather of trauma theory as far as the specifics of colonial trauma are concerned. Moreover, by looking at pervasive racism as a form of "insidious trauma", or by considering "oppression-based trauma", "postcolonial syndrome" or "post-traumatic slavery syndrome", Craps pluralizes the models of trauma at our disposal when we describe postcolonial situations to account for collective, ongoing, everyday forms of traumatizing violence.

6 (2) In chapter 3, Craps deals with "trauma aesthetics", challenging the notion that trauma can only be represented through experimental, modernist textual strategies. Formal experimentation is indeed a recurring feature in the literary output of works dedicated to experiences of trauma, postcolonial and none, and is easily understood as the artistic response to the need to recount a story that is abnormal, a story, that is, that could not be told using conventional literary models. What can be used to explain the formation of this "trauma canon" (41) is the fact that fragmented and antinarrative forms seem to reproduce, on the written page, the psychic experience of trauma. But, Stef Craps argues, it does not need to be so, as this also was arbitrarily predefined, within the European tradition, on the basis of the body of texts dealing with 
the memories of the Holocaust. Drawing on the work by Roger Lockhurst, Jill Bennett and Rosanne Kennedy, Craps revisits the literary history that lies behind trauma theory's preference for experimental, non-representational aesthetics. Starting from Theodor Adorno's famous definition of the barbarity of lyric poetry after Auschwitz and Adorno's own preference for the indirect art of Samuel Beckett, Craps illuminates the extent to which most trauma theorists have dedicated ample pages of text analysis to a very limited selection of, mostly Western, writers whose aesthetics draws on the modernist, and quite elitist, distinction between true art and popular culture, and he warns the reader against such prescriptive stance. Trauma theory should of course be dealing with texts representing a wide range of traumatic experiences in a variety of genres and styles. Craps's call is to be open and receptive to the diverse strategies of representation and resistance that the various experiences of trauma necessitate.

7 (3) The beating heart of Craps' argument is, however, his call for a global and comparative perspective for the field of trauma theory. By examining the textual strategies deployed by different writers working through very different historical contexts, Craps is connecting corpora of texts and intellectual traditions that have always been kept separate (Shoah literature, Afro-Caribbean writing, slavery stories, retellings of other genocides, etc.) looking for points of conjunction, intersection, and mutual illumination. Memory studies - and the Holocaust as their archetype topic need to be put in dialogue with other traumatic events from around the world (the slave trade, apartheid, the genocide of Native Americans, Australia's Stolen Generations all provide excellent examples) if we want to make the field truly global and crosscultural. This means bridging the gap between Jewish and postcolonial studies, a divide that, as many scholars have noted, keeps being maintained despite the evident shared concerns of the two fields as they both deal with histories of violence perpetrated in the name of racist ideologies and imperialist political projects. Craps explores the underlying diffidence in both fields towards incorporation, and, following Rothberg's work in Multidirectional Memory: Remembering the Holocaust in the Age of Decolonization (2009), points to an interesting yet largely overlooked archive of texts bringing histories of genocide, slavery and colonialism together.

8 It is with Craps' contribution to the study of this archive, in the two final chapters analyzing, respectively, the work by Caryl Phillips and Anita Desai, that the book brings its argument full circle. In this operation, Craps brings back narrative and non experimental texts into the mix of acceptable forms for creative works about trauma. Most importantly, by enlarging the framework in which trauma stories are understood, Craps positions his work to explore the larger ethical demand that has traditionally characterized the field of trauma theory. It is crucial to read about other people's suffering in their own terms in order to understand it, to relate to it and to find possible ways to make things better. 


\section{AUTHORS}

\section{SIMONA BERTACCO}

University of Louisville 